Kathmandu School of Law Review (KSLR),

Volume 8, Issue 1, 2020, pp 99-118

https:// doi.org/10.46985/kslr.v8i1.2131

(C) KSLR, 2020

\title{
Compulsory Licensing: An Antidote for the Dissemination of Potential COVID-19 Cure?
}

\author{
Nandini Rajesh* \& Arya Kuttan**
}

\begin{abstract}
This paper extensively examines the role of Compulsory Licensing in the Intellectual Property regime with regard to potential COVID-19 vaccinations. In Parts I and II, the paper analyzes the concept of compulsory licensing along with its need. Part III discusses the usage of the flexibilities laid down by the TRIPS Agreement by developing nations after the adoption of the Doha Declaration. This throws light on the status quo pertaining to its implications and repercussions and further helps in determining the situation upon invoking compulsory licensing in the currentpandemic scenario. Parts $I V$ and $V$ discusses the pre-emptive measures taken by nations by means of laying forth foundational steps and the legal procedures involved in legitimizing the issuance of these licenses for potential COV ID-19 vaccines. It discusses steps taken by various nations across the world, the reasons for doing so and their current legal status pertaining to the licenses. Part VI discusses in detail the diverging views that exist primarily between the United States of America and European Union. It entails discussions regarding accessibility and affordability of potential COVID-19 vaccines in the wake of a jurisprudential analysis of the existing legal provisions relating to compulsory licenses in both provinces. Further, Part VII lays down the negative implications which may arise while invoking compulsory licenses for potential COVID- 19 vaccines. This gives a detailed view of the need for the public healthcare to undertake a balanced approach of the interests of both, the patentee and the public at large. It also lays down the importance of adequate remuneration for the pharmaceutical companies which is often overlooked. Finally, Part VIII analyses both perspectives and lays down the importance of compulsory licensing with regard to both, accessibility and affordability.
\end{abstract}

\section{Introduction}

The COVID-19, alternatively known as the 'Coronavirus', has gripped mankind for a little over 6 months and the effects and repercussions have been destructive till date, resulting in the world coming to a standstill. With approximately 7 lakh (or seven hundred thousand) of the population succumbing to the virus, it has halted daily lives of

\footnotetext{
* Nandini Rajesh is a final year B.A. LL.B. (Hons) student at School of Law, Christ (Deemed to be University), India. She can be reached at nandini.rajesh@law.christuniversity.in.

** Arya Kuttan is a final year B.B.A. LL.B. (Hons) student at School of Law, Christ (Deemed to be University), India. She can be reached at arya.kuttan@law.christuniversity.in.
} 
everyone with ensuing lockdowns in several parts of the world and businesses coming to a standstill. It is pertinent to note that there has been a significant slowdown in the growth of the major economies of the world, with reports stating that the economic consequences arising from the COVID-19 pandemic would result in a severe global economic slope which is predicted to be far worse-off than the 2008 global recession.

While humankind is grappling with the virus at the forefront, nations across the world have dedicated teams of scientists evolving vaccinations to secure everyone and counter the effects of the coronavirus in order to prevent a future outbreak. While most of these vaccines are on their third and final phase of human trials, the question arises as to the significant changes that would be brought about in the international world order post the COVID-19 pandemic.

A significant question which is to be essentially discussed at this stage is that of the concept of compulsory licensing with respect to the potential COVID-19 vaccines which are to be evolved and how it has made a comeback into the sphere of the Intellectual Property regime with nations taking pre-emptive measures to facilitate access to the potential vaccinations. The pharmaceutical industry has always been ardently protective of the existing intellectual property rights and definitely views patents as playing a major role in the arena of innovation. The general rule as provided under the World Trade Organization's (WTO) TRIPS Agreement is such that all WTO members are required to make patents available for any innovative technology. However, it is indeed pertinent to note that there exist various exceptions to the general rule exempting medical countermeasures from the leash of patentability. ${ }^{1}$

\section{The Concept of 'Compulsory Licensing'}

A compulsory licensing is said to be granted in public interest, where an existing patent holder has abused their existing monopoly. ${ }^{2}$ On 14 November, 2001 in the WTO Conference which was held at Doha, various governments of the WTO Members adopted a special Ministerial Declaration whereby inculcating the public health policy factor into the intellectual property regime. ${ }^{3}$ This declaration was thought to be necessary by WTO to remedy the problem caused by patents over pharmaceutical drugs which in turn acts as a barrier to the accessibility of such pharmaceutical drugs to the citizens of developing nations. ${ }^{4}$ Thereby to provide for better access to certain pharmaceutical drugs especially to the developing nation's population the Doha Declaration allowed the member countries to employ the public health policy into the provisions of TRIPS

\footnotetext{
$1 \quad$ Nina M. Hart, 'COVID-19: International Trade and Access to Pharmaceutical Products', Congressional Research Service, 2020, p. 1, available at https://crsreports.congress.gov/product/pdf/LSB/LSB10436, accessed on 15 June 2020.

2 Christopher Garrison, 'Intellectual Property Rights and Vaccines in Developing Countries', World Health Organization, 2004, p.4, available at https://www.who.int/intellectualproperty/events/en/Background_ paper.pdf, accessed on 15 June 2020.

3 World Health Organisation, 'The Doha Declaration on the TRIPS agreement and Public Health', available at https://www.who.int/medicines/areas/policy/doha_declaration/en/, accessed on 15 June 2020.

4 Ibid.
} 
Agreement.

Further the WTO has also provided for certain responses to clear any doubts that may arise on the said declaration. ${ }^{5}$ First, stating that WTO members have the right to enforce the terms of TRIPS which at the same time does not prevent these WTO members from taking necessary measures in relation to public health policy. ${ }^{6}$ Second, that TRIPS should be harmoniously interpreted in a manner to acknowledge the right of WTO member countries to take necessary steps in the benefit of public health. ${ }^{7}$ Last, that the declarations are in line with the member countries obligations under the TRIPS. ${ }^{8}$ These responses thereby give further clarity on the Doha Declaration. The Doha Declaration also provided for certain 'flexibilities' one of them being the right of WTO members to grant a compulsory license. ${ }^{9}$ It is open for the member countries to adopt various flexibilities provided for in the declaration for taking appropriate measures for public health concerns.

Article 30 of the Trade-Related Aspects of Intellectual Property Rights (TRIPS) Agreement provides for certain acts to function as exceptions to the patent monopoly. It is pertinent to note upon this aspect that subject to Article 30, the ambit of patent monopoly is intrinsically limited in terms of the subject matter, the geographical extent and so on. ${ }^{10}$ Essentially, if a patent holder is found to have abused the patent monopoly granted to them or the patent granted is of a public interest, a "compulsory license" may be granted to a third party in order to permit them to carry out any of the acts that the patent holder could have normally forbidden in the alternate scenario. ${ }^{11}$

Therefore, it is essential to note that the concept of compulsory licensing is implemented in a grave situation where the implementation of the license is foreseen as a possible mechanism in order to obtain equal access and affordable treatment for COVID-19. As the race to find a potential vaccine for COVID-19 is reinforced, the only question that lies at the forefront, before the governments and policymakers, is that pertaining to prospective solutions on tackling the availability of the vaccines and its production and distribution to the common man.

\section{Prior Experiences of Invoking Provisions of Compulsory Licensing and its Effects}

While discussing compulsory licensing with regard to potential COVID-19 vaccines,

\footnotetext{
5 World Trade Organisation, 'The separate Doha Declaration explained', available at https://www.wto. org/english/tratop_e/trips_e/healthdeclexpln_e.htm, accessed 16 June 2020.

6 Ibid.

7 Ibid.

8 Ibid.

$9 \quad$ World Trade Organisation, 'TRIPS and public health', available at https://www.wto.org/english/ tratop_e/trips_e/pharmpatent_e.htm, accessed 18 June 2020.

10 Trade-Related Aspects of Intellectual Property Rights Agreement, 1 January 1995, 1869 UNTS 299, Marrakesh, 15 April 1994, art. 30.

11 Ibid, art. 31.
} 
it is important to discuss past experiences from the implementation of compulsory licensing which can yield a variety of opinions and thoughts relating to the matter. It also plays a significant role in highlighting the beneficial aspects of granting these licenses which will serve as a basic premise for granting compulsory licenses even for potential COVID-19 vaccines.

It is essential to note that the intellectual property protection has created various barriers and difficulties for developing nations to implement the varied intellectual property rights in furtherance of facilitating access to essential inventions and drugs. The adoption of the Doha Ministerial Declaration on the TRIPS Agreement and Public Health provisioned sufficient flexibility in terms of adopting measures to protect public health at times of emergency and to facilitate the easy access of medicines across the globe.

The W'TO member nations have collectively agreed that public health crises such as malaria, tuberculosis, HIV/AIDS and other epidemics do indeed constitute a situation of utmost emergency or that of a national emergency. ${ }^{12}$ The current COVID-19 pandemic situation can be brought before the mandate of the TRIPS Agreement in order to ensure access to medicines and drugs, provided that all conditions stipulated within the Agreement have been met with.

It is cardinal to discuss the Doha Declaration for the sole reason that it acts as a legal interpretation of the provisions of the TRIPS Agreement and hence, it upheld the right of member nations of the WTO to grant compulsory licensing on grounds of emergency intertwined with public health. ${ }^{13}$ Further, the Doha Declaration also explicitly uses the term "compulsory licensing", unlike the TRIPS Agreement, thereby throwing more emphasis and creating awareness on the role of compulsory licensing which is an exceptional rule implemented in order to limit the patent rights already granted or which are yet to be granted for the sole purpose of facilitating medicines and drugs at an affordable range. ${ }^{14}$

After the adoption of the Doha Declaration, various countries have made use of the flexibilities incorporated within the TRIPS Agreement, pertaining to the implementation of compulsory licensing. Discussed below are examples of scenarios of least developed, developing and developed nations where compulsory licensing regime was invoked with special emphasis upon the legal premise upon which it was granted, the details pertaining to the decision-making process as well as the public health benefits that entailed the grant of compulsory licensing.

\section{Zimbabwe}

In May 2002, the Ministry of Justice, Legal and Parliamentary Affairs issued a

\footnotetext{
$12 \quad \operatorname{Hart}(\mathrm{n} 1)$, p. 3.

13 Cecilia Oh, 'Compulsory licenses: recent experiences in developing countries', Research Gate p.22, volume 1, 2006, p. 24, available at https://www.researchgate.net/publication/247835566_Compulsory_licenses_ Recent_experiences_in_developing_countries, accessed on 20 June 2020.

14 Ibid.
} 
notification declaring the period of emergency in light of the rapid spread of HIV/ AIDS across the nation. The declaration enabled the State to make or use any antiretroviral patented drug which is used to treat persons suffering from HIV/AIDS or any related condition and it further also permitted the import of any generic drug for the same purpose. ${ }^{15}$ This government use authorization of Zimbabwe provided by means of the emergency declaration is important to be discussed as it is the first license of its kind to be granted by a developing nation post the Doha Declaration.

The declaration which was made in accordance with Section 34 of the Patents Act of Zimbabwe, upon being read with Section 35 provided that the right includes the power to make, use, exercise and sell the invention for any purpose which is considered to be necessary or of utmost emergency. ${ }^{16}$ The declaration which was initially introduced for a period of 6 months and then extended later on for a period of 5 years from January 2003 to December 2008. In the month of April 2003, Varichem Pharmaceuticals Pvt. Ltd., a Zimbabwean registered company was granted authorization under the emergency declaration of the Minister. The company successfully manufactured HIV/ AIDS related antiretroviral drugs termed Combivir at USD 15 per month and also met with $75 \%$ of the governmental needs. They also agreed to provide proof of difference in pricing between the original patentee's drug and their own manufactured drug. ${ }^{17}$

In light of the assigning rights of importing to Datlabs and Omahn to import the drugs from Ranbaxy and Cipla in India, it is evident that the license granted by the government is open in nature and hence there exists multiple licenses which further ensure competitive pricing strategy, which further ensures affordability. ${ }^{18}$

\section{Malaysia}

In 2003, in a dire situation where the public hospitals lacked sufficient drugs at affordable rates, the Minister of Domestic Trade and Consumer Affairs issued a notification which authorized importing of generic antiretroviral drugs used to treat HIV/AIDS, from India. ${ }^{19}$

The imported drugs were to be labelled as 'Ministry of Health, Malaysia' and further a price reduction of the drugs was requested too, as provided under the provision of Section 84 of the Malaysian Patents Act, in light of the emergency situation at hand. While these discussions were underway, the patent holding companies offered discounts in order to dissuade the grant of authorization. However, the Cabinet proceeded with the importation of drugs from GlaxoSmithKline and Bristol-Myers Squibb.

\footnotetext{
15 Declaration of Period of Emergency (HIV/AIDS) Notice 2002 General Notice of Ministry of Justice, Legal and Parliamentary Affairs, Zimbabwe, notice 240

$16 \mathrm{Oh}(\mathrm{n} 13)$, p. 24.

17 Letter of authorisation signed by the Minister of Justice, Legal and Parliamentary Affairs 2003, Ministry of Justice, Legal and Parliamentary Affairs, Zimbabwe

18 Oh (n 13), p. 27.

19 Ibid, p. 28.
} 
Upon a detailed analysis, the repercussions resulting from the importation revealed a significant reduction in the monthly expenditure of treatment. The Combivir drug which cost USD 362.63 per month in the year 2001, saw a significant drop to USD 115.14 , which was solely secured upon the payment of a royalty rate of $4 \%{ }^{20}$

It is cardinal to note that though the authorization granted for government use in Malaysia involved a lengthy process with detailed price negotiations, it resulted in a significant reduction in the monthly expenditure of treatment costs which ensured easy access of essential drugs at affordable rates.

\section{Canada-}

Amongst various steps taken by Canada in terms of compulsory licensing is that where Health Canada, in 2001, overrode the patent granted to Bayer on ciprofloxacin and further permitted the generic manufacturers to produce the same as a form of protection against an attack of certain form of anthrax. ${ }^{21}$ In such a drastic step taken by the Canadian government, it was widely supported by all public health segments and widely criticized by the pharmaceutical industries for overriding the Bayer patents. Further, it also ensured wide and cheap accessibility of the medicine across the country at an extremely dire situation.

Apart from the above examples of how compulsory licensing has facilitated an easy and well-defined access to affordable drugs during times of emergency, there further exist various other examples of countries which have benefited from the granting of compulsory licensing for pharmaceutical products. For instance, as an aftermath of the Doha Declaration, Section 92A was incorporated into the Indian Patents Act, 1970 which facilitated the export of pharmaceutical products to nations with dire need for the same, but possesses minimal or no production capacity in the sector. ${ }^{22}$

In conclusion, it can definitely be ascertained that the granting of compulsory licenses provides a significant benefit to those nations which do not possess sufficient manufacturing capacity of pharmaceutical products. For nations which possess minimal or no such capacity, it is only the concept of granting compulsory licenses which comes to their rescue and hence it is not to be disregarded. It is extremely important for developing nations to draft their national legislations in such a manner which benefits their immediate societies in times of emergency situations. ${ }^{23}$ The essential responsibility of a developing nation in terms of their drug policy is to create a judicious environment

\footnotetext{
20 Ibid.

21 James Packard Love, 'Recent examples of the use of compulsory licenses on patents', Knowledge Ecology International, 2007, p. 7, available at https://www.keionline.org/book/kei-rn-2007-2-recent-examples-ofcompulsory-licensing-of-patents, accessed on 20 June 2020.

22 Raadhika Gupta, 'Compulsory licensing under TRIPS: How Far it Addresses Public Health Concerns in Developing Nations', Journal Of Intellectual Rights p. 357, volume 15, 2010, p. 361, available at http://docs.manupatra.in/newsline/articles/Upload/6A48CA82-9412-43DE-8964-1CAC00062503.pdf, accessed on 27 June 2020.

23 Ruth Gana, 'Prospects for developing countries under the TRIPS Agreement', VJTL p. 735, volume 29, 1996, p. 735.
} 
where these nations ought to disperse drugs and medicines at affordable rates and to further encourage research and development of potential medications.

\section{Intellectual Property Regime in the Current COVID-19 Pandemic Scenario}

In the current scenario, most of the treatments being tested across the world by means of clinical trials have patent rights attached to them. The most promising drug, Favipiravir, used to treat influenza, Chloroquine and Hydroxychloroquine, the combined Lopinavir and Ritonavir which is used to treat HIV and the famous drug termed Remdesivir which was developed by the Gilead Company to treat Ebola, all are protected under the intellectual property umbrella and are patent protected by their respective manufacturing companies. ${ }^{24}$ However, this patent protection which has been granted to these potential treatments for COVID-19, is capable of posing difficulties in the distribution of the vaccine due to its possible high cost. This essentially deems that this intellectual property rights protection granted to these drugs can be a potentially dangerous barrier in relation to the protection of public health.

However, in an exceptional move, despite the protection granted to various pharmaceutical companies, there have been various companies waiving off their rights to patent protection in solidarity to fight the pandemic and its ensuing repercussions. Amongst them include, AbbVie, the pharmaceutical company behind Kaletra. ${ }^{25}$ In light of the same, governments in Chile and Costa Rica have pronounced that the pandemic legitimizes the requirement for extraordinary measures to guarantee licensed innovation rights which do not forestall worldwide access to medicines. ${ }^{26}$

\section{Pre-emptive Measures Taken by Nations with Regard to Compulsory Licensing Regime}

In order to curb the potential barrier to public health that patent protection may give rise to, various governments across the world have resorted to the powerful tool of compulsory licensing. The effect of the onset pandemic, COVID-19 is most likely to affect in a larger magnitude to countries with least developing and developing economies than the developed nations. According to the data of the Word Bank on world development indicators where they characterized countries by income for analytical purposes, it may very well be seen that the earning capacity with respect to a larger part of the population of the countries with developing economies falls either below or slightly above the poverty line. ${ }^{27}$ Further it holds true for these least

\footnotetext{
24 Samantha Silver \& Lindsay Maclean, 'COVID-19: vaccine development and compulsory licensing', Kennedys, 2020, available at https://www.kennedyslaw.com/thought-leadership/article/covid-19-vaccinedevelopment-and-compulsory-licensing, accessed on 30 June 2020.

25 Ibid.

26 Ibid.

27 Lucas Volman, The TRIPS Article 31 Tug of War: Developing Country Compulsory Licensing of Pharmaceutical Patents and Developed Country Retaliation, LL.M. Intellectual Property and Information Technology Law Thesis, University of Dublin, 2018, p. 19.
} 
developing and developing economies that they also have an additional disadvantage owing to their poor infrastructural arrangements especially medical infrastructural arrangements. ${ }^{28}$ Therefore it would in all probability will further lead to a situation where these countries would not be in position to adequately cater to the needs of its population under these extraordinary circumstances.

The people in the entire world are eagerly waiting for a successful cure to be found for COVID-19 to get a relief from these unprecedented hard times that has affected almost every part of the world without any discrimination and beyond any boundaries. Unfortunately, even in the event of there being found a cure for COVID-19 a larger part of the population, who are barely even able to afford the bare necessities to survive especially in these developing countries would find it impossible to afford these medicines for the very reason that these medicines in all likelihood would be patented. In other words, it means that by way of patenting by various pharmaceutical companies, these potential life-saving pharmaceutical drugs or medicines will be made prohibitively expensive making it harder for these countries with developing economies to afford them in the first place. Thereby leading to a situation where a major part of the population is out of reach of the potential cure for an ongoing pandemic which has a high rate of transmission.

It is only predictable that these pharmaceutical companies will have an aim to recoup the investment made on the Research and Development on the vaccine or cure so discovered by making profits thereby will doubtlessly set the prices for the same quite high. Therefore, the use of a mechanism that would result in cheaper and more affordable means of acquiring or producing these potential cures for COVID-19 can just be said to be an important advance by various countries given the present unprecedented situation.

It is necessary to note here that the issuance of compulsory license can be said to be a viable option given there are adequate domestic mechanisms or legislative enactments to authorise such an issuance of license in that particular country. As the compulsory license is a kind of involuntary contact between the patentee who is not willing and buyer who is willing and also wants a license to produce or sell a particular product for which only the former has license, the same is enforced by the state ${ }^{29}$ in consonance to the state's domestic law governing the same. Therefore, given the present situation various countries are laying foundational steps to legitimize the issuance of compulsory license as they do not have in place a compulsory license. Governments of Chile and Costa Rica have pronounced that the pandemic legitimizes the requirement for extraordinary measures to guarantee licensed innovation rights which do not forestall worldwide access to medicines. ${ }^{30}$ The following are certain countries which resorted to

\footnotetext{
28 Ibid.

29 Anuradha Mukherjee, Ashwin Sapra, Pallavi Rao, Biplab Lenin \& Shivanshu Bhardwaj, 'To Protect or Not to Protect that is the Question: Patent Licensing in times of Covid-19 Pandemic', India Corporate Law, 2020, available at https://corporate.cyrilamarchandblogs.com/2020/05/patent-licensing-in-times-of-covid-19pandemic/, accessed on 6 July 2020.

$30 \quad$ Grace Ren, ‘ WHO, Costa Rica \& Chile Announce Official Launch Of COVID-19 Intellectual Property
} 
Intellectual Property Right is specific compulsory licensing to prioritise and safeguard the health of its citizens during the ongoing pandemic.

On March 17,2020 the Chilean Chamber of Deputies which it's lower house of Congress passed a resolution with an overwhelming majority which would give the government of Chile the authority to grant compulsory license for vaccines, pharmaceutical drugs and any other useful technology which can be potentially be used for either the treatment or prevention of COVID-19. ${ }^{31}$ Further the head of the advocacy group, Corporacion Innovarte which lead the movement in Chile for a such a resolution to be passed rightly made a statement that such a move by the government will strengthen the already existing legal mechanism which provides for access to technologies that are important for fighting COVID-1932 re-affirming the need of such an action in the present scenario.

The Article L.613-16 of the Intellectual Property Code of France contemplates the issuance of compulsory license in France and there are three conditions under the Article to be fulfilled for the compulsory license to be granted. ${ }^{33}$ On March 23, 2020 the government introduced a new article, L.3131-15 under its Public Health Code which gives the government certain powers to be used to make sure the adequate medicines are available to the citizens. ${ }^{34}$ Among the powers there certain Intellectual Property related provisions too which can also cover granting of compulsory license. ${ }^{35}$ The new Article provides for a much easier process to grant compulsory license than under the existing Article L.613-16 of the Intellectual Property Code of France. ${ }^{36}$

In light of the same, after Israeli Ministry of Health opined that the generic drug version of lopinavir and ritonavir of AbbVie's patented Kaletra drug could be a possible cure for COVID-19 the government of Israel issued a compulsory license on March 24, 2020 for importation. ${ }^{37}$ The importation of the antiretroviral drug which

Pool', Health Policy Watch, 2020, available at https://healthpolicy-watch.news/who-costa-rica-announceofficial-launch-of-covid-19-intellectual-property-pool, accessed on 10 July 2020.

31 Luis Gil Abinader, 'Chilean Chamber of Deputies approves resolution for compulsory licenses for patents relating to the coronavirus virus', keionline.org, 2020, available at https://www.keionline.org/32385, accessed on 10 July 2020.

32 Ed Silverman, 'Chilean lawmakers support compulsory licensing for coronavirus medicines and vaccines', STAT Pharmalot, 2020, available at https://www.statnews.com/pharmalot/2020/03/18/chile-compulsorylicensing-coronavirus-covid19-vaccines/, accessed on 16 July 2020.

33 Amy Sandys, 'Forced cure: compulsory licensing in the coronavirus era', juve-patent.com, 2020, available at https://www.juve-patent.com/news-and-stories/legal-commentary/forced-cure-compulsory-licensingin-the-coronavirus-era/, accessed on 18 July 2020.

34 Steven Cattoor \& Ine Letten, 'Legislative initiatives on compulsory licensing in light of Covid-19', exgo.be/ en, 2020, available at https://www.lexgo.be/en/papers/ip-it-telecom/intellectual-property-law/legislativeinitiatives-on-compulsory-licensing-in-light-of-covid-19,136382.html, accessed on 21 July 2020.

35 Nirmalya Syam, 'Countries Are Adapting Intellectual Property Laws to Prioritise Health During COVID-19', thewire.in, 2020, available at https://thewire.in/trade/intellectual-property-laws-covid-19, accessed on 22 July 2020.

36 Cattoor \&Letten (n 34).

37 Hilary Wong, 'The case for compulsory licensing during COVID-19', Journal of Global health, volume 10:1, 2020, available at https://www.ncbi.nlm.nih.gov/pmc/articles/PMC7242884/, accessed on 24 July 2020. 
potentially could be the treatment is to be made mainly from India. ${ }^{38}$ Even though this particular generic version of the antiretroviral drug which initially was thought of as possible a cure has been proven ineffective. ${ }^{39} \mathrm{It}$ is interesting to note here that as mentioned earlier certain pharmaceutical companies have waived off their rights to patent protection in solidarity to fight the pandemic and AbbVie is also one of them, ${ }^{40}$ resulting in a free environment for generic companies to produce these antiviral drugs in large scale without inviting any patent infringement.

On March 25, 2020 the Canadian Government's COVID-19 Emergency Response Act (Bill C-13) received the royal assent. ${ }^{41}$ The main aim of this particular legislation is to provide for an effective action plan to protect the Canadian population from the adverse impact of the COVID-19. ${ }^{42}$ One of the responses to the COVID-19 provided for in the Act is to ensure availability of the necessary pharmaceutical drugs and medical devices and such a move would give the Canadian government the power to aid to any future shortage of pharmaceutical drugs or medical devices by taking appropriate measures which in health emergency situation would also include to allow for drug patent overrides in the period up to September 30, 2020.43 The COVID-19 Emergency Response Act (Bill C-13) thereby would also effectively amend the Canadian Patent law. ${ }^{44}$ Whereby Section 19.4 has been added to the Canadian Patent Act which has a time limit added to it that is a compulsory license can be only issued under this new section till September 30, 2020 as mentioned earlier and Section 19.4 also entitles a non-governmental entity to obtain a license under it. ${ }^{45}$ Furthermore it is also pertinent to note here that this is not the first time Canada is using the compulsory licensing tool in the pharmaceutical industry it has a history of implementing these measures since the 1990 's. ${ }^{46}$

On March 20, 2020 the National Assembly of Ecuador passed a resolution which would require the Minister of Health to grant compulsory license over patented products or

38 Okan Çan, 'Turkey: Compulsory or Not? Licensing during the Covid-19 Pandemic', mondaq.com,2020, https://www.mondaq.com/turkey/patent/940300/compulsory-or-not-licensing-during-the-covid-19pandemic, accessed on 27 July 2020.

39 Andrew Green, 'COVID-19: Countries race to strengthen compulsory licensing legislation', Devex, 2020, available at https://www.devex.com/news/covid-19-countries-race-to-strengthen-compulsory-licensinglegislation-97595, accessed on 27 July 2020.

40 Okan Çan (n 38).

41 Department of Finance, 'The COVID-19 Emergency Response Act Receives Royal Assent', wmw.canada. ca, 2020, available at https://www.canada.ca/en/department-finance/news/2020/03/the-covid-19emergency-response-act-receives-royal-assent $0 . h t m l$, accessed on 29 July 2020.

42 Ibid.

43 Ibid.

44 Hilary Wong (n 37).

45 Nathaniel Lipkus, Simon Hodgett \& Jaymie Maddox, 'Government COVID-19 response includes compulsory licenses for patented emergency medical needs', osler.com, 2020, available at https://www.osler. $\mathrm{com} /$ en/resources/regulations/2020/government-covid-19-response-includes-compulsory-licenses-forpatented-emergency-medical-needs, accessed on 29 July 2020.

46 Stephen I. Selznick \& Any Obando, 'COVID-19 Impact: Changes to the Canadian Compulsory Licensing Scheme', Cassels Insight, 2020, available at https://cassels.com/insights/covid-19-impact-changes-to-thecanadian-compulsive-licensing-scheme/, accessed on 29 July 2020. 
pharmaceutical drugs to provide for easy access to COVID-19 treatment, diagnosis or the related technologies of the same. ${ }^{47}$ The Minister of Health would be empowered to take these actions under Article 510 of the Código Ingenios of Ecuador. ${ }^{48}$

Further the Joint United Nations Programme on HIV/AIDS(UNAID) in Geneva on May 14, 2020 drafted an open letter which demands that all the medicines or pharmaceutical drugs or vaccines for the treatment against COVID-19 and tests conducted to diagnose the same should be patent free. ${ }^{49}$ The same open letter has been signed and advocated by the 140 world political leaders who also advocate that such vaccines and the technology so related should just be patent free but all be mass produced where there should be a fair distribution system of the same so that everyone has access to the same. ${ }^{50}$ Further it also states that not just vaccines or medicines should be shared but any but the accompanying knowledge in relation to COVID-19 should also be shared. ${ }^{51}$ This is a very important step by the UNAID as it is an extremely important call given the present situation that the world is going through as everyone needs to stand in solidarity to fight the deadly pandemic together. As by creating an information asymmetry or creating barriers to access to these vaccines or medicine will only worsen the situation.

Even European Parliament also conveyed their support for the usage of compulsory license during this pandemic for COVID-19 vaccine. ${ }^{52}$

Therefore, it can be seen that there have been sweeping proactive steps that have been taken by the countries across the world to ensure that the citizens of their country have sufficient access to the treatment, cure and related technology in relation to COVID-19. Further it is important that countries especially developing countries who are yet to take preventive measures in order to evaluate their legal systems to analyse if existing legal regimes may be used in case there is a barrier created to access to the treatment, cure and related technology in relation to COVID-19.53

It has also been taken into consideration that the countries using Compulsory License as a measure to ensure access to healthcare to its citizens cannot issue the same without necessary guidelines. For instance, a country which is a WTO member cannot just

$47 \quad$ Luis Gil Abinader, 'Legislative Committee in Ecuador approves resolution on compulsory licensing of patents relating to the coronavirus', keionline.org, 2020, available at https://www.keionline.org/32429, accessed on 29 July 2020.

48 Ibid.

49 UNAIDS, 'World leaders unite in call for a people's vaccine against COVID-19', UNAIDS, 2020, available at https://www.unaids.org/en/resources/presscentre/pressreleaseandstatementarchive/2020/ may/20200514_covid19-vaccine, accessed on 30 July 2020.

50 Ibid.

51 Adam Houldsworth, 'Global calls for compulsory covid-19 patent licensing build', iam-media.com, 2020, available at https:/ / www.iam-media.com/coronavirus/global-calls-compulsory-covid-19-patent-licensingbuild, accessed on 30 July 2020.

52 Ibid.

53 Nirmalya Syam (n 35). 
blatantly subject an entire class of medicines or pharmaceutical drugs as 'essential' thereby subjecting them to the compulsory licensing regime. ${ }^{54}$ But have to decide on the particular facts on case to case basis and not a blanket application and further it also had be made sure that such patentee should be paid adequate remuneration ${ }^{55}$ for the research and development put into such discovery of a new or finding of a new use of an already existing medicine. Therefore, it is important that while granting a compulsory license there ought to be adequate balancing of the need to safeguard public health and the rights of a patent holder. In the event that countries do not protect the rights of such patent holders while also providing access to public health care it might lead to discouragement of these pharmaceutical companies who invest a huge amount of research and development into these innovations or discoveries.

\section{Diverging Views on Compulsory Licensing- Analysis of the USA and the EU Approaches}

In the wake of the current COVID-19 pandemic situation that has grasped the world, as discussed above, questions arise relating to the universal access and affordability of the potential COVID-19 vaccines. It is at this stage that it is pertinent to discuss the diverging opinions on compulsory licensing that arise between the United States of America and the European Union, which constitute a substantial segment of the world's economy. While several treaties and international congresses ${ }^{56}$ have been successful in creating fundamental equity and consistency among national patent laws, complete stability is difficult to achieve as a result of various philosophies with regard to free enterprise, monopoly rights, and technological development.

The TRIPS Agreement provides for an international minimum standard which is to be implemented by the member countries in their own appropriate method as provided for under their own respective legal systems and methods. ${ }^{57}$ However, it is essential to note that the Agreement being of a minimum standard, prescribes for more protection to be laid down, but not less, under any scenario. ${ }^{58}$

In comparison to the concept of compulsory licensing, voluntary licensing offers an alluring alternative option for foreign patent holders as it is a prevalent and superior strategy for penetrating a foreign market with practically no investment and labour contribution, advantages absent when manufacturing occurs directly in the foreign country. ${ }^{59}$ When given a choice between direct production in a foreign nation and

${ }_{54}$ Jerome H. Reichman, 'Comment: Compulsory Licensing of Patented Pharmaceutical Inventions:
Evaluating the Options', Journal of Law, Medicine \& Ethics p. 247, volume 37:2, 2009, p. 252.
Ibid, p. 252.
${ }_{55}$ Paris Convention for the Protection of Industrial Property, 7 July 1884, 828 UNTS 305, Paris, 20 March 1883.
Nafsika Karavida, Dara Onofrio \&Deena Merlen, 'Patent Rights and Wrongs in the COVID-19 Pandemic:
EU and U.S. Approaches to Compulsory Licensing', IP Watchdog, 2020, available at https://www.
ipwatchdog.com/2020/05/19/patent-rights-wrongs-covid-19-pandemic-eu-u-s-approaches-compulsory-
licensing/id=121709/, accessed on 30 July 2020.
Ibid.
Robert T. Jones, 'Fundamentals of International Licensing Agreements and Their Application in the 
licensing to a generic local based company, the former method is adopted by many United States enterprises due to the various advantages and profits encompassed when a particular company decides to produce the drugs themselves. ${ }^{60}$ However, what is essential to be noted is that foreign jurisdictions and nations offering and providing for strong and non-negotiable compulsory licenses inhibit this specific method adopted by businesses with extensive resources. ${ }^{61}$

\section{Position of the United States of America-}

The United States is said to hold minimal sympathy for compulsory licensing, as a result of significant lobbying efforts by large firms, especially in the biotech and pharmaceutical industry. ${ }^{62}$ The basic premise upon which the United States' argument is based on is that while compulsory licenses are essentially invoked to remedy the non-use, misuse or patent suppression, the United States strongly believes that actual misuse of a patent protection by an inventor has not been proven in order to grant compulsory licenses. ${ }^{63}$ This premise believes that the concept of non-use is purely a myth and any patented invention which is important enough to have compulsory license granted would already be exploited. Though the 1908 case of Continental Paper Bag Co. vs. Eastern Paper Bag Co. ${ }^{64}$ exposed instances whereby a potentially important patent was indeed proved to be suppressed by its owner, ${ }^{65}$ the Supreme Court determined and further laid down that patentee could enforce its patent rights and prevent a competitor from using its process. Despite the Paper Bag case and various other examples of suppression of patent protection, the United States has consistently maintained that such a form of suppression is not sufficiently pervasive to warrant adoption of compulsory licenses. ${ }^{66}$

Further, the United States is also of the view that compulsory licenses reduce the inventor's incentive to develop new technology. It is a norm that it is only rightful of the business enterprises wanting to be compensated for not just the expenses incurred in the actual invention and research but also all the other costs and expenses which have been utilized for the purpose of researching other ideas which did not prove

European Community', International Lawyer p.78, volume 7, 1973, p. 80, available at https://scholar.smu. edu $/$ cgi/viewcontent.cgi? article $=3918 \&$ context $=$ til, accessed on 31 July 2020 .

$60 \quad$ Ibid, p. 82.

61 Arthur H. Seidel, What the General Practitioner Should Know about Patent Law and Practice, Joint Committee on Continuing Legal Education of the American Law Institute collaborating with the American Bar Association, US, 4th edition, 1984, p. 97.

62 Donna M. Gitter, 'International Conflicts Over Patenting Human DNA Sequences in the United States and the European Union: An Argument for Compulsory Licensing and a Fair-Use Exception', New York University Law Review, p. 1623, volume 76, 2001, p. 1681, available at https://www.nyulawreview.org/wpcontent/uploads/2018/08/NYULawReview-76-6-Gitter.pdf, accessed on 31 July 2020.

63 Catherine S Corry, Compulsory Licensing of Patents-A Legislative History :Study of the Sub-Committee on Patents, Trademarks and Copyrights of the Senate Committee on the Judiciary, 85th Congress, 2D Session, Washington D.C. 10, United States Government Printing Office, United States, 1958.

64 Continental Paper Bag Co. v Eastern Paper Bag Co., Supreme Court of United States, 1908, 210 U.S., p. 405.

65 Ibid, p. 424.

66 Senate Committee on the Judiciary (n 63). 
to be patentable or profitable in any form or manner. In inventions involving high research and development costs and in comparison, the success rate remains low, an exclusive right of patent protection is mandatorily to be provided in order to recoup the large sums spent as start-up costs. ${ }^{67}$ Compulsory licensing, in this sense, strips off business enterprises from recouping the costs incurred and hence provides a potentially dangerous barrier.

Another prominent argument consistently brought about, however never addressed in the courts as general compulsory licensing laws have never been passed, is that compulsory licenses are unconstitutional and ultra vires their Constitution. Their argument is two-fold. The first argument is based on the text of the Constitution which provides for the right of Congress to grant exclusive rights over inventions in order to promote science and arts. ${ }^{68}$ As per the argument raised, the constitutional power to grant this exclusive rights to inventions does not encompass the power to encroach upon that right which has been granted or to grant any right which is constrained upon any ensuing governmental interference. ${ }^{69}$ The second argument on unconstitutionality of the compulsory licenses regards these licenses as a taking, reflecting and further promoting the contention that a patent right is essentially a form of property right which is not to be taken away, unless provided with a fair compensation. ${ }^{70}$

It is widely stated that compulsory licenses hurt the United States in international trade $^{71}$ and this argument is based on the premise that compulsory licensing facilitates easy entry of foreign enterprises to enter and compete in the United States market by providing access to any patented invention or product. The contention laid down by United States is that nations which are unable to afford such level of research and development, would be able to combine the efforts of research developed by United States along with the cheap labour force available in their respective nations in order to arrive and place themselves at a competitive position in comparison to the United States enterprises. ${ }^{72}$

From the perspective of a contract theory, granting of a patent protection constitutes an agreement between the government and the inventor, ${ }^{73}$ where the inventor agrees to reveal the research and all details of the discovery of the invention and the means to use it in return for the government's promise of a seventeen-year monopoly over the production of the invention. According to this, compulsory licensing may be interpreted as a failure of consideration on the part of the government, or even a

\footnotetext{
David J. Henry, 'Multi-National Practice in Determining Provisions in Compulsory Patent Licensing', J. Int'l L. \& Econ p. 325, volume 11, 1976, p. 329.

68 Constitution of the United States, 1788, art I, s 8, cl 8.

69 B. R. Pravel, 'Say No to More Compulsory Licensing Statutes', Asia- Pacific Lawyers Association, volume 2:3, 1974, p.185.

70 Ibid, p. 189.

71 T. Arnold \& P. Janicke, ‘Compulsory Licensing Anyone?’,J. PAT. OFF. SOc'Y, volume 55, 1973, p. 165.

72 Leroy Whitaker, 'Compulsory Licensing-Another Nail in the Coffin', PAT. L.A.Q.J. p.155, volume 2 , 1974, p.168.

73 Application of Bayer (C.C.P.A. 1978) 568 F.2d 1357.
} 
breach of contract should a compulsory license be granted retroactively. According to this theory, compulsory licenses definitely constitute a taking and even if they do not acquire the constitutional specifications of a taking, ${ }^{74}$ they may still be viewed as a process of complete injudicious expropriation of the private property. ${ }^{75}$

The closest that the United States of America comes to the process of invoking compulsory licenses is only by a right granted to government agencies to compel licensing of a federally-funded patent, which is commonly referred to as "march-in rights". This further provides the government with the right to override the patent protection which has already been granted, and to grant licenses to various applicants, provided that the patent owner has not taken sufficient steps to achieve the application of the invention or is not reasonably satisfied with the public health and safety needs among others conditions. ${ }^{76}$

In the current scenario, the United States has clearly taken leave from multinational efforts to facilitate vaccines and drugs for COVID-19. Their absence from the virtual EU-led summit on developing vaccines to fight the pandemic is a clear depiction of the same. It is essential that the potential vaccine will require international supply and pursuing a winner-take-all approach, similar to the current pattern followed by the United States, in the manufacturing of a potential vaccine is likely to result in a great risk in the near future as it will definitely harm and create a barrier in the potential COVID-19 vaccines reaching the public at affordable rates. ${ }^{77}$

\section{Position of the European Union-}

The law regarding the concept of compulsory licensing in the European Union is extremely challenging due to the presence of a mix of national laws of the Member States along with that of the European Union government which is sitting in Brussels. ${ }^{78}$ It is to be noted that in comparison to the United States, the Member States of the European Union are extremely transparent nations and for all those foreign enterprises which desire to enter into the European Union's market can actually easily accomplish the same with an adequate level of study. ${ }^{79}$

Articles 34, 36, 101 and 102 of the Treaty on the Functioning of the European Union

\footnotetext{
$74 \quad$ Pravel (n 69).

75 Cole M. Fauver, 'Compulsory Patent Licensing in the United States: An Idea Whose Time Has Come', Nw. J. Int'l L. \& Bus p.666, volume 8, 1988, p .681.

76 Michael Liu, William B. Feldman, Jerry Avorn \&nAaron S. Kesselheim, 'March-In Rights and Compulsory Licensing- Safety Nets for Access to a COVID-19 Vaccine', Health Affairs Blog, 2020, available at https:// www.healthaffairs.org/do/10.1377/hblog20200501.798711/full/, accessed on 31 July 2020.

77 William Alan Reinsch, Jack Caporal \& Sanvid Tuljapurkar, 'Compulsory Licensing: A Cure for Distributing the Cure?', Center for Strategic \& International Studies, 2020, available at https://www.csis.org/analysis/ compulsory-licensing-cure-distributing-cure, accessed on 2 August 2020.

78 Christopher Wadlow, Enforcement of Intellectual Property in European and International Law, Sweet \& Maxwell, 1st edition, 1998, p. 257.

79 Christopher J. Meyers, 'European Union Competition Law and Intellectual Property Licensing: TransAtlantic Convergence and Compulsory Licensing', AIIPL p. 135, volume 11, 2005, pp. 149-150.
} 
provides for the scope and limitations of the concept of compulsory licensing along with its rights and remedies, within the European Union, pertaining to its Member States. The Regulations which have been passed by the European Council apply transparently to all Member States and do not provide them with a discretion as to whether to implement it or not. ${ }^{80}$ In comparison to Regulations, Directives are a source of federal law which facilitate a level of flexibility with regard to its implementation by the Member States. ${ }^{81}$ Since the European Union Member States are parties to the Paris Convention, the Berne Convention, and the World Trade Organization, ${ }^{82}$ the balance between these sources of international law and the national laws of the Member States is essentially struck by the European Commission and the European Court of Justice. ${ }^{83}$

The favourable attitude which is adopted by the European Union stems from the fact that historically in Europe, intellectual property rights are viewed with an eye of suspicion for being associated or causing various forms of barriers in the market. ${ }^{84}$ It has been consistently argued that the European Union approach to competition/antitrust laws is preferable to that of the United States' as compulsory licenses permit the powerful firms to stay intact in the European scenario, whereas the approach followed by the United States requires the powerful firm to be dissolved. ${ }^{85}$ This approach which is religiously followed by the European Union permits the powerful firms to stay intact by ensuring the efficiencies of scale and also that these efficiencies are passed onto the public in the form of compulsory licenses to competitors. ${ }^{86}$

The attempt by the World Intellectual Property Organization to create a global patent system addresses the concept of compulsory licensing ${ }^{87}$ and this remains one of the most significant attempts for the harmonization of the concept of compulsory licensing amongst the Member States of the European Union. ${ }^{88}$ The European Union Member States provide for compulsory licensing of medicines and vaccines, provided that certain conditions are fulfilled, to least developed and developing nations across

80 Christopher Bellamy \& Graham D. Child, 'European Union Law of Competition', in Peter Roth QC \& Vivien Rose (eds), Oxford University Press, 2008, p. 26.

$81 \quad$ Ibid, p. 1047.

82 Meyers (n. 79), pp. 143-144.

83 Ibid.

84 Rita Coco, 'Antitrust Liability for Refusal to License Intellectual Property: A Comparative Analysis and the International Setting', Marq. Intell. Prop. L. Rev, volume 12, 2008, p. 10.

85 Melanie J. Reichenberger, 'The Role of Compulsory Licensing in Unilateral Refusals to Deal: Have the United States and European Approaches Grown Further Apart After IMS?', J. Corp. L p. 563, volume 31, 2006, pp. 563-564.

86 Reichenberger (n 85), pp. 564-565.

87 Susan K. Sell, 'The Quest for Global Governance in Intellectual Property and Public Health: Structural, Discursive, and Institutional Dimensions', Temp. L. Rev. p. 363, volume 77, 2004, pp. 385-386, available at https://www.researchgate.net/publication/239928829_The_Quest_for_Global_Governance_in_ Intellectual_Property_and_Public_Health_Structural_Discursive_and_Institutional_Dimensions, accessed on 2 August 2020.

88 World Intellectual Property Organization, 'Member States', available on https://www.wipo.int/members/ en/, accessed on 2 August 2020. 
the world in pursuance of the EU Regulation (EU) No. 816/2006. ${ }^{89}$

Hence it is essential to note that with respect to the United States and the European Union, the varying nature of the existence of compulsory licensing is of a concerning character. European countries do indeed permit compulsory licensing in order to facilitate the availability of inventions and vaccines and to encourage their public access in order to fight against a specific public health emergency, unlike the United States, which is extremely restrictive in nature. It is also essential to note that the European Union in a strikingly contrasting opinion to that of the United States has a specific law which provides for granting of compulsory licenses as long as the conditions under Article 31 of the TRIPS Agreement is fulfilled. This plays a major role in driving a prominent worldwide interest upon the European Union vaccine development process and further will facilitate in speeding up the path to developing a COVID-19 vaccine, which is required across the world.

\section{Repercussions of Introducing Compulsory Licensing into the COVID-19 Scenario}

As many countries take proactive steps to legitimize the use of compulsory license it is necessary to evaluate the repercussions that may follow from the grant of a compulsory license. It has to be understood that from the invoking of compulsory license and till the time the product so manufactured or imported reaches the actual beneficiaries, the whole process might consume a lot of time and at the same time can be cumbersome in nature. For instance on August 30, 2003 the World Trade Organisation made a very important decision which would allow poorer countries to import generic medicines under the compulsory licensing regime in a much cheaper and easier manner if that particular country is unable to produce the medicines within their domestic territory..$^{90}$ Canada was the first country to inculcate this decision of the WTO through its legislation, Canada's Access to Medicines Regime (CAMR) which lays down a system for such export to be carried out to a least developed country or developing countries. ${ }^{91}$ When Canada agreed to export to Rwanda a fixed dose of pharmaceutical drugs which is mainly used to treat HIV/AIDS, the same was to be produced by a Canadian pharmaceutical company called Apotex. ${ }^{92}$ Here in the present case it is crucial to note that it took almost 5 years for the whole process of granting the compulsory license to the actual export to take place and reach the people in Rwanda. If such a situation or delay were to occur in the event of there being a vaccine found for COVID-19 then the issuance of compulsory license might not be a very attractive option.

\footnotetext{
89 Karavida, Onofrio \& Merlen (n 57).

90 World Trade Organisation, 'Decision removes final patent obstacle to cheap drug imports', available at https://www.wto.org/english/news_e/pres03_e/pr350_e.htm, accessed on 2 August 2020.

91 Padmanabha Ramanujam \& Yugank Goya, 'One View of Compulsory Licensing: Comparative Perspectives from India and Canada', Marq. Intellectual Property L. Rev p. 369, volume 18, 2014, p. 400.

92 Ibid.
} 
It is also true that there has been a history of successful invoking of compulsory license as mentioned earlier but however it must be ensured that in situations of such health emergencies like the onset pandemic an adequate mechanism should be provided for. This mechanism should ensure that there is a system intact which will check on administrative delays caused by various domestic regulations. It becomes crucial to invoking a compulsory license that such delay does not act as a hurdle for the actual beneficiaries to avail the medicines in a timely manner.

Further Professor R.C Birds argues that the use of compulsory licensing in developing countries may cause certain repercussions or retaliation. ${ }^{93}$ Professor R.C. Birds explains the repercussions that follow after the issuance of a compulsory license which is of broad nature by giving the examples of Egypt and South Africa. Both countries in their efforts to provide for their citizens easier access for certain medicines had to face black lash from a lot of pharmaceutical companies. These pharmaceutical companies who were dissatisfied by the issuance of such compulsory license in Egypt's case also moved on to threaten to take steps to retract foreign direct investment from the country. ${ }^{94}$ Therefore it can be understood that the grant of compulsory license might result in retaliations from the dissatisfied pharmaceutical companies which will in turn affect the economy of the country issuing such compulsory licenses. Further there will also be unnecessary wastage of time in the process as these dissatisfied pharmaceutical companies may also resort to litigation. Whereby it becomes necessary that these legislations empowering for issuance of compulsory license should not be ambiguous and should be used for only limited or specific purposes.

The fear of such retaliations of these pharmaceutical companies often acts as a disincentive for the developing countries to even issue a compulsory license in the first place. As such retaliation can negatively impact the country's trade relation and also hamper future investments into the country. It can be gathered from various incidents that developed nations like the United States pressurize these developing or low-income nations to conform to a stricter intellectual property regime and thereby dissuading these nations from issuing compulsory license. ${ }^{95}$

Another repercussion that may follow the issuance of a compulsory license is that this move might disincentive pharmaceutical companies to strive for innovation. It is a well-known fact that there is a huge amount of capital, research and development that goes into these innovations and it is only justified for pharmaceutical companies to expect protection for such an innovation. This is exactly one of the main reasons for developed nations to adopt stricter intellectual property regimes. Such strict intellectual property regimes will incentivize these pharmaceutical companies to strive for better and speedier innovations thereby increasing the productivity level. ${ }^{96}$ Cole M. Fauver argues

\footnotetext{
93 R. C. Bird, 'Developing Nations and the Compulsory License: Maximizing Access to Essential Medicines while Minimizing Investment Side Effects', JLME p. 209, volume 37, 2009, p. 211.

94 Ibid, p. 212.

95 Gupta (n 22), p. 359.

96 Ibid.
} 
that under such a regime where these pharmaceutical companies are being provided for a monopoly it will in turn benefit the country and the issuance of a compulsory license on the contrary will may truncate the incentive for these pharmaceutical companies. ${ }^{97}$

Given the current situation where the whole world is going through a pandemic, people around the globe are in anticipation of a vaccine to be found. Which means that research, development and innovation can be said to be the need of the hour. The world is eagerly looking forward to the pharmaceutical companies and the research and development wings of various countries to come up with a vaccine for COVID-19. For that very reason it becomes extremely necessary that while granting a compulsory license with regard to a pharmaceutical drug, the country issuing the same has to make sure that interest of both the patentee and public in general i.e., public healthcare should be taken into consideration in a balanced approach. It is also to be ensured by the countries issuing such compulsory licenses that it should be issued only be for a specific or limited purpose and such issuance should be empowered by a domestic legislation which is not vague, ambiguous or broad in its provisions. Further it is also crucial that these pharmaceutical companies are adequately compensated for their efforts in the event of the issuance of a compulsory license.

\section{Conclusion}

There is no question on the fact that the topic of compulsory licensing has been most widely discussed and debated in the arena of pharmaceutical products. Innovation and health improvements play a major role in stimulating economic development. ${ }^{98}$ Through this paper, we do not fundamentally establish that compulsory licensing is the way forward and that is indeed left to the readers. However, we lay forth our arguments in support of the compulsory licensing regime and upon an analysis of its grant and the implications that it derives, we can conclude that the advantages of granting compulsory licensing for potential COVID-19 vaccines outweigh the issues it may entail with regard to legal framework, scope of implementation, international obligation, royalty fee and available funds and so on.

Our analysis has been done by comparing the prior experiences with respect to granting of licenses in least developed, developing and developed nations, which further explains differences that may arise in intra-country legal structures. Though, our analysis may possibly include inherent limitations with regard to any unforeseen contingency which could come across while granting compulsory licenses to potential COVID-19 vaccines, this can however be essentially dismissed, as an overall analysis of the scenario reveals that the positive effects clearly outweigh the disadvantages which nations may face. As a primary step in managing compulsory licensing for the purpose of ensuring that consumers get adequate access to the potential COVID-19 vaccines at an affordable

\footnotetext{
$97 \quad$ Fauver (n 75), p. 668.

98 David E. Bloom \& David Canning, 'The Health and Wealth of Nations', Science p. 1207, volume 287:5456, 2000, p. 1209, available at https://science.sciencemag.org/content/287/5456/1207.summary, accessed on 3 August 2020.
} 
rate, these vaccines must be sold without any delay at the lowest profitable rates to the nations requiring them. It is also essential to mold the compulsory licenses in line with the affected interest at hand in order to ensure that the research and development laid in by companies is not prejudiced.

Research and development arising out of a public-private partnership ${ }^{99}$ ensures wide scale information sharing among nations and also accelerates the accessibility coupled with efficient and innovative produce. Since pharmaceutical companies resist compulsory licensing regimes due to the requirement to significantly lower the prices of their products, it is essential to introduce large scale alternate sources of funding which will facilitate these companies to provide potential vaccines to fight COVID-19 at a lower rate, which will further increase accessibility.

Most nations have laid down state obligations which promote public healthcare towards all citizens. In nations where this has not been expressly laid down, there exists inherent state obligations which provide for the same. At unprecedented times like the COVID-19 pandemic scenario, invoking the provisions of compulsory licensing may be viewed as an extension of such obligation of the state to improve public healthcare which further facilitates access to affordable vaccines, especially in poorer nations.

In conclusion, access to affordable vaccines can be eased into the countries, most effectively by invoking the provisions of compulsory licensing with adequate measures to ensure that access to these essential vaccines is maximized at a substantially cheap price.

99 $\quad$ Frederick M. Abbott, 'IP and Public Health: Meeting the Challenge of Sustainability', Working Paper No. 7/2011, Global Health Programme, Geneva, Switzerland, 2011, p. 32, available at http://ssrn.com/ abstract $=1965458$, accessed on 3 August 2020. 